\title{
Topical Treatments for Seborrheic Keratosis: A Systematic Review
}

\author{
Ma. Celina Cephyr C. Gonzalez, Veronica Marie E. Ramos and Cynthia P. Ciriaco-Tan \\ Department of Dermatology, College of Medicine and Philippine General Hospital, University of the Philippines Manila
}

\begin{abstract}
Background. Seborrheic keratosis is a benign skin tumor removed through electrodessication, cryotherapy, or surgery. Alternative options may be beneficial to patients with contraindications to standard treatment, or those who prefer a non-invasive approach.
\end{abstract}

Objectives. To determine the effectiveness and safety of topical medications on seborrheic keratosis in the clearance of lesions, compared to placebo or standard therapy.

Methods. Studies involving seborrheic keratosis treated with any topical medication, compared to cryotherapy, electrodessication or placebo were obtained from MEDLINE, HERDIN, and Cochrane electronic databases from 1990 to June 2018.

Results. The search strategy yielded sixty articles. Nine publications (two randomized controlled trials, two nonrandomized controlled trials, three cohort studies, two case reports) covering twelve medications (hydrogen peroxide, tacalcitol, calcipotriol, maxacalcitol, ammonium lactate, tazarotene, imiquimod, trichloroacetic acid, urea, nitric-zinc oxide, potassium dobesilate, 5-fluorouracil) were identified. The analysis showed that hydrogen peroxide $40 \%$ presented the highest level of evidence and was significantly more effective in the clearance of lesions compared to placebo.

Conclusion. Most of the treatments reviewed resulted in good to excellent lesion clearance, with a few welltolerated minor adverse events. Topical therapy is a viable option; however, the level of evidence is low. Standard invasive therapy remains to be the more acceptable modality.

Key Words: seborrheic keratosis, topical, systematic review

\section{INTRODUCTION}

\section{Description of the condition}

Seborrheic keratoses (SK) are very common benign tumors of the hair-bearing skin, typically seen in the elderly population. They present as solitary or multiple, tan to brown verrucous papules and plaques with a "stuck-on" appearance. Although very common, epidemiologic studies are limited. ${ }^{1}$ Dermatologists manage roughly $85 \%$ of patients who seek consult for seborrheic keratosis. Nearly half of them want the lesions removed. ${ }^{2}$

The etiology of seborrheic keratoses has not yet been

E-poster presented at the $41^{\text {st }}$ Annual Convention of the Philippine Dermatological Society, November 7-9, 2018, Edsa Shangri-La Hotel, Mandaluyong, Philippines.

Corresponding author: Ma. Celina Cephyr C. Gonzalez, MD Department of Dermatology

Philippine General Hospital

University of the Philippines Manila

Taft Avenue, Manila 1000, Philippines

Email: mcgonzalez@up.edu.ph clearly elucidated, but several factors have been implicated such as genetics, sun exposure, and infection. ${ }^{3}$ The hypothesized transmission is autosomal dominant with incomplete penetrance. ${ }^{1}$ Sun-exposed areas such as the face have a higher prevalence of lesions. Seborrheic keratoses have also been associated with viral warts due to their clinical similarities. ${ }^{3}$ 
Patients usually seek to consult if the lesion is cosmetically disfiguring or if they are worried about a potential malignancy. If atypical looking, a biopsy of the lesion may be warranted. ${ }^{4}$

\section{Dermatosis Papulosa Nigra (DPN)}

In dark-skinned individuals, a histologically identical variant of seborrheic keratosis may occur. Lesions present as multiple, small, brown papules on the skin of patients with a Fitzpatrick type of IV or higher. They tend to appear at an earlier age compared to seborrheic keratoses. Other schools of thought classify DPN as a variant of multiple fibroepithelial papillomata. ${ }^{1}$

\section{Topical Therapy in Seborrheic Keratosis}

Currently accepted treatment modalities include cryotherapy, electrodessication, laser vaporization, or surgery. Common complications are pigmentary changes, scarring, incomplete removal, and recurrence. ${ }^{3}$ The ideal method would be the one that reduces the chances of scarring.

In the United States, topical hydrogen peroxide was recently approved by the Food and Drug Administration for the treatment of raised seborrheic keratosis. Currently, this is the only FDA-approved topical treatment for seborrheic keratosis.

A number of topical treatments for seborrheic keratosis have been investigated. However, there is limited data supporting the use of such agents.

\section{Significance of the Review}

Although invasive modalities have been the treatment of choice for seborrheic keratosis, topical therapy may prove to be an acceptable alternative for some patients. It would be best for patients with pacemakers requiring a thermal desiccator or patients with contraindications to standard treatment options. Topical therapy may be more affordable since anesthesia and machines won't be needed, may have fewer complications and may possibly be offered as a home treatment in the future.

This review will report on the available studies regarding the use of topical treatments for seborrheic keratosis.

\section{OBJECTIVES}

The primary objective of this review is to determine the effectiveness of topical medications on seborrheic keratosis in the clearance of lesions, compared to placebo or standard therapy.
The secondary objective of this review is to determine the safety of topical medications on seborrheic keratosis compared to placebo or standard therapy.

\section{METHODS}

\section{Search Strategy}

The literature search was conducted on the following electronic databases: PubMed, HERDIN, and Cochrane from 1990 to present. The last search was run on June 12, 2018. The keywords used were "seborrheic keratosis", "seborrheic keratoses", "topical", "treatment", and "therapy". The full electronic search strategy from PubMed is shown in Figure 1.

\section{Searching other resources}

A review of the references of the retrieved articles was done to search for other eligible studies that were not available in the electronic databases mentioned.

\section{Study Selection}

Studies comparing the effectiveness of topical treatments versus cryotherapy, electrodessication or placebo in the clearance of seborrheic keratosis in adults were included in this review. Those without comparison groups were included as well. Due to the limited amount of studies related to the topic of interest, all experimental studies with human subjects were included. No language, publication date, or publication status restrictions were imposed. Initial screening was done using titles and abstracts. Included studies then underwent full-text review.

\section{Data Extraction}

A form for data extraction was filled out with the following information: authors, study design, year, country, age of participants, sample size, number of lesions, size, location, Fitzpatrick type, outcome measure, frequency and duration of treatment, follow-up duration and results of the study. The mean values of the number of subjects, age of participants, lesion size, and clearance time were summarized. One author extracted the information from the studies included while the other verified the data obtained. Disagreements in the data gathered were resolved through discussion between authors.

\section{Quality Assessment of Included Studies}

Assessment of risk of bias was done using RevMan version 5.3 from Cochrane as shown in Table 1. Possible

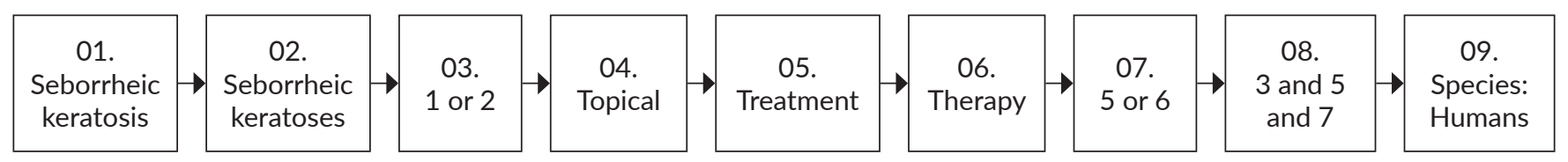

Figure 1. Search strategy: PubMed. 
Table 1. Assessment of risk of bias using RevMan 5.3

\begin{tabular}{lcccc} 
Sources of Bias & Vitamin D3 & $\begin{array}{c}\text { Hydrogen } \\
\text { peroxide }\end{array}$ & $\begin{array}{c}\text { Ammonium } \\
\text { lactate }\end{array}$ & $\begin{array}{c}\text { Calcipotriene, tazarotene, } \\
\text { imiquimod }\end{array}$ \\
\hline Random Sequence Generation (Selection Bias) & Low & Low & High & High \\
Allocation Concealment (Selection Bias) & Unclear & Low & High & High \\
Binding of Participants and Personnel (Performance Bias) & Unclear & Low & Low & High \\
Blinding of Outcome Assessment (Detection Bias) & Unclear & Low & Low & High \\
Incomplete Outcome Data (Attrition Bias) & High & Low & High & High \\
Selective Reporting (Reporting Bias) & Low & High & Low & High \\
\hline
\end{tabular}

causes of bias were identified by answering questions on random sequence generation, allocation concealment, blinding, incomplete data outcome, reporting bias, and other bias. The risk of bias would be then classified as high, unclear or low risk. ${ }^{5}$ Case reports and cohort studies were not assessed for quality.

\section{RESULTS}

\section{Database Search}

The electronic search yielded 60 results, with four duplicates noted. The remaining fifty-six articles were screened by title and abstract, after which only 10 full-text articles met the selection criteria. The study flow diagram is shown in Figure 2.

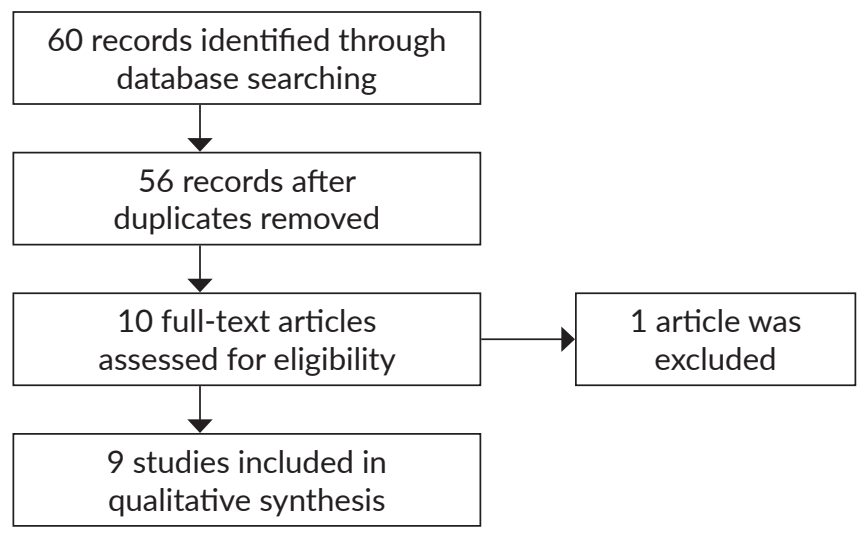

Figure 2. Study flow diagram.

Out of the ten articles which underwent a full-text evaluation, one study was excluded. This was a case series conducted in 2005 by Orence et al. in assessing the effect of imiquimod on facial warts. In their abstract, they included patients with verruca plana, as well as seborrheic keratosis. ${ }^{6}$ However, upon reviewing the final paper, they defined facial warts as verruca plana only.

A total of nine studies were included in this systematic review - two randomized controlled trials, two nonrandomized controlled trials, three cohort studies, and two case reports. The qualitative data extraction and results are shown in Tables 2 and 3, respectively.

The assessment of the quality of evidence is shown in Table 1 . The randomized controlled trials involving vitamin
D3 and hydrogen peroxide had low to unclear risk of bias, associated with the highest level of evidence. The rest of the studies had a high risk of bias.

\section{Randomized Controlled Trials}

\section{Hydrogen Peroxide $\left(\mathrm{H}_{2} \mathrm{O}_{2}\right)$ 32.5\%, Hydrogen Peroxide $40 \%$ Solution}

This vehicle-controlled clinical trial compared two concentrations of a hydrogen peroxide-based solution $32.5 \%$ and $40 \% .119$ patients with seborrheic keratosis lesions on the face were enrolled in this study. The mean diameter of the lesions was $10.3 \mathrm{~mm}$. Most patients had a Fitzpatrick Type of III, with a mean age of 70 . There were more males than females. Treatment was applied by the physician up to two times on day 1 and day 22. Only lesions that have not yet cleared were subjected to the second round of treatment. The amount applied was just enough to evenly coat the entire lesion. Clearance of lesion was evaluated using physician and subject assessment at baseline and on days 8, 22, 29, 50, 78 and 106. Serial measurements of the diameter of the lesions were done. The investigators used the Physician's Lesion Assessment (PLA) scale with the following classification: 0 - Clear: no visible seborrheic keratosis (SK) lesion; 1 Near Clear: a visible SK lesion with a surface appearance different from the surrounding skin (not elevated); 2 - Thin: a visible SK lesion (thickness $\leq 1 \mathrm{~mm}$ ); and 3 - Thick: a visible SK lesion (thickness $>1 \mathrm{~mm}$ ). Patients were also asked to assess clinical response to treatment using the Subject's SelfAssessment Scale: 0 - None: no visible SK lesion; 1 - Mild: a slightly raised, light-brown SK lesion; 2 - Moderate: an obvious raised, brown SK lesion; and 3 - Severe: a prominent rough, dark SK lesion. Adverse events were also described using the Local Skin Reaction Assessment Scale: 0 - None; 1 - Mild; 2 - Moderate; and 3 - Severe. At the end of the study, PLA scores showed that $60 \%$ of the patients in the hydrogen peroxide $40 \%$ group had complete clearance of lesions, compared to $46 \%$ in the hydrogen peroxide $32.5 \%$ group and $3 \%$ in the vehicle group. Similar findings were also seen in the SSA scores. $70 \%$ of the patients treated with hydrogen peroxide $40 \%$, 54\% with hydrogen peroxide $32.5 \%$, and $10 \%$ with vehicle had complete clearance of lesions. Results showed that hydrogen peroxide $40 \%$ was superior to hydrogen peroxide $32.5 \%$ and vehicle. Adverse events noted between day 0 and 106 were seasonal allergy, upper 
Table 2. Qualitative data extraction on included studies (Study Characteristics and Baseline Demographics of Subjects)

\begin{tabular}{|c|c|c|c|c|c|c|c|}
\hline \multirow{2}{*}{$\begin{array}{c}\text { Authors (Year) } \\
\text { Country/Study Design }\end{array}$} & \multicolumn{2}{|c|}{ Treatment Groups ( $\mathrm{N}=$ Sample Size) } & \multirow{2}{*}{ Lesions } & \multirow{2}{*}{ Size } & \multirow{2}{*}{ Location } & \multirow{2}{*}{ Results } & \multirow{2}{*}{ Outcome Measure } \\
\hline & Treatment & Control & & & & & \\
\hline $\begin{array}{l}\text { Dubois et al. (2017) } \\
\text { USA } \\
\text { RCT }\end{array}$ & $\begin{array}{l}\text { 1. } \mathrm{H}_{2} \mathrm{O}_{2} 32.5 \% \text { (39) } \\
\text { 2. } \mathrm{H}_{2} \mathrm{O}_{2} 40 \% \text { (39) }\end{array}$ & 1. Vehicle (41) & 1 & $7-15 \mathrm{~mm}$ & Face & $\begin{array}{l}\text { 1. Reduction in } \\
\text { size } \\
\text { 2. Patient } \\
\text { satisfaction } \\
\text { 3. Clearance of } \\
\text { lesions }\end{array}$ & $\begin{array}{l}\text { 1. Physician's Lesions } \\
\text { Assessment } \\
\text { 2. Subject's Self- } \\
\text { Assessment } \\
\text { 3. Disappearance of } \\
\text { lesions }\end{array}$ \\
\hline $\begin{array}{l}\text { Mitsuhashi et al. (2005) } \\
\text { Japan } \\
\text { RCT } \rightarrow \text { omitted control }\end{array}$ & $\begin{array}{l}\text { 1. Tacalcitol } 2 \mu \mathrm{g} / \mathrm{g} \\
\text { (45) } \\
\text { 2. Calcipotriol } 50 \\
\mu \mathrm{g} / \mathrm{g}(34) \\
\text { 3. Maxacalcitol } 25 \\
\mu \mathrm{g} / \mathrm{g} \text { (37) }\end{array}$ & $\begin{array}{l}\text { 1. } 30 \rightarrow \\
\text { omitted }\end{array}$ & $\begin{array}{c}\text { Not } \\
\text { specified }\end{array}$ & $\begin{array}{c}\text { None } \\
\text { indicated }\end{array}$ & $\begin{array}{c}\text { None } \\
\text { indicated }\end{array}$ & $\begin{array}{l}\text { 1. Decrease in } \\
\text { volume }\end{array}$ & 1. Photographs \\
\hline $\begin{array}{l}\text { Klaus et al. (1990) } \\
\text { USA } \\
\text { Non-randomized } \\
\text { controlled trial }\end{array}$ & $\begin{array}{l}\text { 1. } 12 \% \text { ammonium } \\
\text { lactate lotion (58) }\end{array}$ & 1. Vehicle (58) & 1 & $\begin{array}{c}\text { None } \\
\text { indicated }\end{array}$ & $\begin{array}{c}\text { None } \\
\text { indicated }\end{array}$ & $\begin{array}{l}\text { 1. Reduction in } \\
\text { height, length, } \\
\text { number of } \\
\text { lesions } \\
\text { 2. Reduction in } \\
\text { pigmentation, } \\
\text { change in } \\
\text { surface } \\
\text { characteristics }\end{array}$ & $\begin{array}{l}\text { 1. Elevation, length, } \\
\text { number of lesions } \\
\text { 2. Surface and } \\
\text { pigment } \\
\text { characteristics }\end{array}$ \\
\hline $\begin{array}{l}\text { Herron et al. (2004) } \\
\text { Utah } \\
\text { Non-randomized } \\
\text { controlled trial }\end{array}$ & $\begin{array}{l}\text { 1. Tazarotene cream } \\
0.1 \% \text { daily (15) } \\
\text { 2. Tazarotene cream } \\
0.1 \% \text { 2x/day (15) } \\
\text { 3. Calcipotriene } \\
\text { ointment } 0.005 \% \\
\text { daily (15) } \\
\text { 4. Calcipotriene } \\
\text { ointment } 0.005 \% \\
2 x / \text { day (15) } \\
\text { 5. Imiquimod cream } \\
5 \% \text { daily (15) } \\
\text { 6. Imiquimod cream } \\
5 \% 2 x / \text { day (15) }\end{array}$ & $\begin{array}{l}\text { 1. Cryosurgery } \\
\text { (15) } \\
\text { 2. Moisturizer } \\
\text { daily (15) } \\
\text { 3. Moisturizer } \\
\text { BID (15) }\end{array}$ & 1 & $5-15 \mathrm{~mm}$ & $\begin{array}{l}\text { Chest, } \\
\text { back, } \\
\text { upper } \\
\text { arms }\end{array}$ & $\begin{array}{l}\text { 1. Clinical } \\
\text { improvement } \\
\text { 2. Histologic } \\
\text { improvement }\end{array}$ & $\begin{array}{l}\text { 1. Replacement of } \\
\text { lesion by normal } \\
\text { appearing skin } \\
\text { 2. Normalization } \\
\text { of epithelium } \\
\text { on biopsy }\end{array}$ \\
\hline $\begin{array}{l}\text { Chun et al. (2004) } \\
\text { Korea } \\
\text { Non-randomize } \\
\text { open-label study }\end{array}$ & 1. $65 \%$ TCA (23) & None & $\begin{array}{c}\text { Not } \\
\text { specified }\end{array}$ & $\begin{array}{c}\text { None } \\
\text { indicated }\end{array}$ & Face & $\begin{array}{l}\text { 1. Clinical } \\
\text { improvement } \\
\text { 2. Patient } \\
\text { satisfaction } \\
\text { 3. Recurrence }\end{array}$ & $\begin{array}{l}\text { 1. Clinician's } \\
\text { assessment - } \\
\text { excellent, good, } \\
\text { poor, fair } \\
\text { 2. Interview - } \\
\text { absolutely, } \\
\text { moderately, } \\
\text { not at all } \\
\text { 3. Repeat assessment }\end{array}$ \\
\hline $\begin{array}{l}\text { Burkhart et al. (2008) } \\
\text { USA } \\
\text { Non-randomized } \\
\text { open-label }\end{array}$ & $\begin{array}{l}\text { 1. } 50 \% \text { urea ointment } \\
\text { with a vehicle } \\
\text { containing vitamin } \\
\text { E, lactic acid, zinc } \\
(20)\end{array}$ & None & $\begin{array}{c}\text { Not } \\
\text { specified }\end{array}$ & $\begin{array}{l}\text { Thick, } \\
\text { large }\end{array}$ & $\begin{array}{c}\text { Trunk } \\
\text { and/or } \\
\text { extremity }\end{array}$ & $\begin{array}{l}\text { 1. Patient } \\
\text { satisfaction }\end{array}$ & $\begin{array}{l}\text { 1. 0-point scale - } \\
\text { lower score: no; } \\
\text { higher score: yes }\end{array}$ \\
\hline $\begin{array}{l}\text { Lacarrubba et al. (2017) } \\
\text { Italy } \\
\text { Non-randomized } \\
\text { open-label }\end{array}$ & $\begin{array}{l}\text { 1. Nitric-zinc oxide } \\
\text { solution, organic } \\
\text { acids (acetic, lactic, } \\
\text { oxalic acid), copper } \\
\text { salt, water (15) }\end{array}$ & None & 50 & $5-15 \mathrm{~mm}$ & $\begin{array}{l}\text { Trunk, } \\
\text { legs }\end{array}$ & $\begin{array}{l}\text { 1. Clinical } \\
\text { clearance } \\
\text { 2. Dermoscopic } \\
\text { clearance } \\
\text { 3. Recurrence } \\
\end{array}$ & $\begin{array}{l}\text { 1. 5-point score - } \\
\text { complete, good, } \\
\text { partial, poor, } \\
\text { no response }\end{array}$ \\
\hline $\begin{array}{l}\text { Cuevas et al. (2012) } \\
\text { Spain } \\
\text { Case report }\end{array}$ & $\begin{array}{l}\text { 1. } 5 \% \text { potassium } \\
\text { dobesilate cream } \\
\text { (1) }\end{array}$ & None & 2 & $\begin{array}{c}\text { None } \\
\text { indicated }\end{array}$ & Face & $\begin{array}{l}\text { 1. Clearance } \\
\text { 2. Recurrence }\end{array}$ & $\begin{array}{l}\text { 1. Disappearance of } \\
\text { lesions } \\
\text { 2. Repeat assessment }\end{array}$ \\
\hline $\begin{array}{l}\text { Tsuji et al. (1995) } \\
\text { Japan } \\
\text { Case report }\end{array}$ & 1. 5\% fluorouracil (1) & None & 1 & $8 \times 6 \mathrm{~cm}$ & Scalp & $\begin{array}{l}\text { 1. Clearance } \\
\text { 2. Recurrence }\end{array}$ & $\begin{array}{l}\text { 1. Disappearance of } \\
\text { lesions } \\
\text { 2. Repeat assessment }\end{array}$ \\
\hline
\end{tabular}


Table 3. Qualitative data extraction on included studies (Results)

\begin{tabular}{|c|c|c|c|c|c|}
\hline Intervention & $\begin{array}{l}\text { Frequency of } \\
\text { Application }\end{array}$ & $\begin{array}{l}\text { Treatment } \\
\text { Duration }\end{array}$ & Follow-Up & Efficacy & $\begin{array}{c}\text { Safety } \\
\text { (Adverse Events) }\end{array}$ \\
\hline $\begin{array}{l}\text { Hydrogen } \\
\text { peroxide } 32.5 \% \\
\text { and } 40 \%\end{array}$ & $\begin{array}{l}\text { One to two } \\
\text { applications, } \\
21 \text { days apart }\end{array}$ & 22 days & 106 days & $\begin{array}{l}\text { 1. PLA: } 60 \%\left(\mathrm{H}_{2} \mathrm{O}_{2} 40 \%\right) \text { and } 46 \% \\
\left(\mathrm{H}_{2} \mathrm{O}_{2} 32.5 \%\right) \text { clearance vs } 3 \% \text { in } \\
\text { vehicle } \\
\text { 2. } \mathrm{SSA}: 70 \%\left(\mathrm{H}_{2} \mathrm{O}_{2} 40 \%\right) \text { and } 54 \% \\
\left(\mathrm{H}_{2} \mathrm{O}_{2} 32.5 \%\right) \text { clearance vs } 10 \% \text { in } \\
\text { vehicle group }\end{array}$ & $\begin{array}{l}\text { Seasonal allergy (6) } \\
\text { Upper respiratory tract infection (5) } \\
\text { Bleeding (1)* } \\
\text { Malignant melanoma (1) } \\
\text { Metastatic neoplasm (1) } \\
\text { Dizziness (1) } \\
\text { Renal failure (1) } \\
\text { Cataract (1) } \\
\text { Local skin reactions } \\
{ }^{*} \text { Only treatment-related adverse event }\end{array}$ \\
\hline Vitamin D3 & $\begin{array}{l}\text { Once or } \\
\text { twice daily }\end{array}$ & $\begin{array}{l}\text { Up to } 12 \text { months } \\
\text { (Mean: } 7.3 \\
\text { months) }\end{array}$ & 12 months & $\begin{array}{l}\text { 1. } 30 \% \text { excellent clinical response } \\
\text { 2. } 47 \% \text { good clinical response } \\
\text { Calcipotriol = maxacalcitol < } \\
\text { tacalcitol }\end{array}$ & No erythema, swelling, scar \\
\hline $\begin{array}{l}\text { Ammonium } \\
\text { Lactate } 12 \%\end{array}$ & Twice daily & 16 weeks & None & $\begin{array}{l}\text { 1. Significant reduction in height of } \\
\text { lesions in the treatment group } \\
\text { 2. No significant difference in width } \\
\text { of lesions in either the study or } \\
\text { control group } \\
\text { 3. No significant difference in } \\
\text { surface characteristics and } \\
\text { pigment of lesions in either the } \\
\text { study or control group }\end{array}$ & Not discussed \\
\hline $\begin{array}{l}\text { Tazarotene } \\
0.1 \%, \\
\text { Calcipotriene } \\
0.005 \%, \\
\text { Imiquimod 5\% }\end{array}$ & $\begin{array}{l}\text { Once to } \\
\text { twice daily }\end{array}$ & 16 weeks & 6 months & $\begin{array}{l}\text { 1. Once-daily application did not } \\
\text { result in clinical improvement } \\
\text { 2. } 47 \% \text { complete clearance } \\
\text { with tazarotene BID vs } 100 \% \\
\text { with cryosurgery vs 0\% with } \\
\text { moisturizer BID }\end{array}$ & $\begin{array}{l}\text { 1. Redness, burning, ulceration in } \\
5 \text { patients treated with imiquimod } \\
\text { 2. Irritation which improves within } \\
1 \text { month with tazarotene }\end{array}$ \\
\hline $\begin{array}{l}\text { Trichloroacetic } \\
\text { Acid } 65 \%\end{array}$ & $\begin{array}{l}\text { Every 1to } \\
2 \text { months }\end{array}$ & $\begin{array}{c}\text { Until clinical } \\
\text { clearance (Mean: } \\
6 \text { weeks) }\end{array}$ & $\begin{array}{l}\text { More than } \\
13 \text { months }\end{array}$ & $\begin{array}{l}\text { 1. } 86 \% \text { fair to excellent clinical } \\
\text { response } \\
\text { 2. } 78 \% \text { and } 13 \% \text { were absolutely } \\
\text { and moderately satisfied, } \\
\text { respectively }\end{array}$ & $\begin{array}{l}\text { 1. Mild erythema, transient post- } \\
\text { inflammatory hyperpigmentation } \\
\text { 2. No persistent erythema, } \\
\text { permanent hyperpigmentation, } \\
\text { hypopigmentation, scarring, keloid }\end{array}$ \\
\hline Urea $50 \%$ & Once-daily & $\begin{array}{l}\text { Until clinical } \\
\text { clearance }\end{array}$ & 6 weeks & Some reduction of thickness & No side effects \\
\hline Nitric-zinc oxide & $\begin{array}{l}\text { Every other } \\
\text { week }\end{array}$ & $\begin{array}{l}\text { Until clinical or } \\
\text { dermoscopic } \\
\text { clearance (Max of } \\
4 \text { applications) }\end{array}$ & 6 months & $\begin{array}{l}\text { 74\% complete clinical and } \\
\text { dermoscopic clearance }\end{array}$ & $\begin{array}{l}\text { Slight transient, post-treatment } \\
\text { erythema, minimal residual } \\
\text { hypopigmentation }\end{array}$ \\
\hline $\begin{array}{l}\text { Potassium } \\
\text { Dobesilate } 5 \%\end{array}$ & Once-daily & 6 months & 1 year & Complete clearance & $\begin{array}{l}\text { No application-site reactions, } \\
\text { skin atrophy, disturbances in } \\
\text { pigmentation or skin thinning }\end{array}$ \\
\hline Fluorouracil 5\% & Once-daily & 21 days & 7 years & $\begin{array}{l}\text { Normal skin } 6 \text { months post- } \\
\text { treatment }\end{array}$ & $\begin{array}{l}\text { Erythema, edema, erosion, post- } \\
\text { inflammatory pigmentation }\end{array}$ \\
\hline
\end{tabular}

respiratory tract infection, bleeding, malignant melanoma, metastatic neoplasm, dizziness, renal failure, cataract, and local skin reactions. However, among these, the only treatment-related adverse event was when a patient scratched a lesion resulting in mild, transient bleeding. Recurrence of lesions was not evaluated. ${ }^{7}$

\section{Tacalcitol $2 \mu \mathrm{g} / \mathrm{g}$, Calcipotriol $50 \mu \mathrm{g} / \mathrm{g}$, Maxacalcitol $25 \mu \mathrm{g}$ Ointments}

One hundred sixteen patients with seborrheic keratosis lesions were randomly assigned to receive one of the three vitamin D3 ointments - tacalcitol $2 \mu \mathrm{g} / \mathrm{g}$, calcipotriol 50 $\mu \mathrm{g} / \mathrm{g}$, maxacalcitol $25 \mu \mathrm{g}$. On the same patients, 30 lesions were treated with the control which was petrolatum alba containing $10 \%$ salicylic acid. However, the control group was eventually omitted because of the lack of improvement in the lesions. The mean age of patients was 65.6 years old. More females participated in this study compared to males. The number, size, and location of lesions, as well as Fitzpatrick skin type of the patients, were not indicated. Medications were applied by the patients once or twice daily for up to 12 months. Lesions were serially photographed tangentially and horizontally. The volume of the lesions was also measured at baseline and after treatment. Clinical 
improvement was classified as follows: excellent - decreased more than 80\%; good - decreased between $40-80 \%$, and; poor - decreased less than $40 \% .30 \%$ of all lesions treated with topical vitamin D3 showed excellent improvement. The most improvement was seen in the maxacalcitol group, with $15 \%$ of patients showing an excellent response, compared with $12 \%$ in the calcipotriol group, and $8 \%$ in the tacalcitol group. The mean application period was 7.3 months. There were no noted adverse events such as erythema, swelling and scar formation. The recurrence of lesions was not evaluated. A separate laboratory study was done which involved organ cultures of seborrheic keratosis lesions with different concentrations of tacalcitol. However, this is not included in the scope of the review and will not be discussed here. ${ }^{8}$

\section{Non-Randomized Controlled Trials}

\section{Ammonium Lactate 12\% Lotion}

This study compared the efficacy of ammonium lactate $12 \%$ lotion compared to its vehicle in the treatment of 58 patients with at least two seborrheic keratosis lesions. The size and location of the lesions, as well as Fitzpatrick type, were not specified. The ages of the patients were between 37 to 82. The sex of the patients were not indicated. Per patient, one lesion was treated with ammonium lactate and another with the vehicle. Patients applied the medication twice daily for 16 weeks. Height, length, color, surface characteristics were measured using a $7 \mathrm{x}$ calibrated loupe, a template, skin replicas, and a scanning electron microscope. Lesion pigmentation was classified as skin-colored, light brown, or dark brown. Surface characteristics were categorized as flat, smooth, keratotic or verrucoid. In the treatment group, there was an average decrease in the height of lesions from $0.761 \mathrm{~mm}$ at baseline to $0.648 \mathrm{~mm}$ at week 16 , which was significant. However, there was no significant difference in width, surface characteristics and pigment of lesions in either the study or control group. Treatment adverse events and recurrence of lesions were not evaluated. ${ }^{9}$

\section{Tazarotene 0.1\% Cream, Calcipotriene 0.05\% Ointment, Imiquimod 5\% Cream}

In this study, topical tazarotene, calcipotriene, and imiquimod were compared with moisturizers and cryosurgery. Once a day application of each medication was compared with twice a day application. Fifteen patients with nine seborrheic keratosis lesions were recruited. Each lesion was treated with one of the following: Tazarotene cream $0.1 \%$ daily, tazarotene cream $0.1 \%$ twice daily, calcipotriene ointment $0.005 \%$ daily, calcipotriene ointment $0.005 \%$ twice daily, imiquimod $5 \%$ cream daily, imiquimod $5 \%$ twice daily, moisturizer daily, moisturizer twice daily, or cryosurgery. Lesions were $5-15 \mathrm{~mm}$ in size on the chest, back or upper arms. More females compared to males participated in the study. The mean age of women was 56 years, and men, 70 years. Fitzpatrick skin type was not specified. Patients were treated with topical medications for four months. Cryosurgery was performed once. Clinical and histologic clearance were evaluated. Before treatment, lesions were photographed, their diameters were measured, and their circumference outlined with wax paper. Lesions were monitored monthly for any change in size. Adverse events were also documented using photographs. At the end of treatment, lesions were removed using the shave technique and analyzed under the microscope. Clinical clearance was described as the complete absence of the lesion, while histologic clearance implied the normalization of the epithelium. Any residual clinical or histologic evidence of the lesion was considered no improvement. The results of the study showed that oncedaily application did not result in clinical improvement. Tazarotene twice a day resulted in $47 \%$ complete clinical and histologic clearance compared to $0 \%$ in the moisturizer group. All patients treated with cryosurgery had complete resolution of lesions. Adverse events seen were redness, burning and ulceration in lesions treated with imiquimod twice daily, and transient irritation in lesions treated with tazarotene. Cryosurgery caused edema, blister formation, crusting and erosion, with complete re-epithelialization after 1 month. Recurrence of lesions was not evaluated. ${ }^{10}$

\section{Cohort Studies}

\section{Trichloroacetic Acid 65\% Peel}

A total of 106 dark-skinned patients with benign pigmented lesions on the face were recruited for this study. Twenty-three of them had seborrheic keratosis lesions. The rest had solar lentigines, freckles or melasma. The mean age of subjects was 40.5 years, with a Fitzpatrick type of IV-V. More females compared to males participated in the study. The number and size of lesions were not indicated. Depending on the type of lesion, a specific concentration of Trichloroacetic Acid was applied. For seborrheic keratosis, $65 \%$ TCA peel was applied focally on the lesion using a sharpened wooden applicator. The frosted appearance of the lesion was used to monitor treatment. The endpoint was an evenly frosted spot. Peeling was performed every one to two months until the desired effect was achieved. Clearance was evaluated using clinical assessment and patient satisfaction rates. Photographs of the lesions were taken before and 6 months after completion of treatment. Two blinded independent investigators categorized clinical improvement as follows: Excellent - with an improvement greater than 70\%; Good - with an improvement of 50\% to 70\%; Fair - with an improvement of 30-50\%; and Poor with an improvement less than $30 \%$. Patient satisfaction rate was measured using individual interviews conducted 6 months after treatment with the following classification: Absolutely - satisfaction rate over 70\%; Moderately satisfaction rate $50 \%$ to $70 \%$; and Not at all - satisfaction rate less than 50\%. Results of the clinician's assessment indicated that $57 \%$ of patients had an excellent response to treatment, 
while $58 \%$ of patients reported absolute satisfaction. Results were maintained for more than 13 months. Compared with other pigmented lesions, the improvement was greatest in patients with seborrheic keratosis and solar lentigines. The mean number of treatments administered was 1.5 for seborrheic keratosis. Adverse events included mild erythema and transient post-inflammatory hyperpigmentation which resolved spontaneously over one to two months. There were no persistent erythema, permanent hyperpigmentation, hypopigmentation, scarring, or keloid formation. ${ }^{11}$

\section{Urea 50\% Ointment}

Twenty patients with thick, large seborrheic keratosis lesions on the trunk and/or extremities were recruited. The number of lesions and Fitzpatrick skin type were not indicated. More females compared to males participated in the study. Mean age and mean number of lesions were not identified. Patients were instructed to apply the medication once daily until the desired effect was achieved. Scraping of the lesions with the patient's fingernails once or twice a week was done. Clearance was evaluated using a survey conducted six weeks after the initiation of treatment. Patients were asked to answer five questions regarding clinical improvement and patient satisfaction with medication. Responses were selected from a scale of 1 to 10 , with 1 meaning that the product did not help at all, and 10 meaning that the product was fantastic. The researchers concluded that there was some reduction of thickness with no noted side effects. The mean treatment duration was not specified. Recurrence was not evaluated. ${ }^{12}$

\section{Nitric-Zinc 30-50\% Solution}

Fifteen patients with a total of 50 lesions on the trunk and legs were recruited. The size of lesions ranged from 5 to $15 \mathrm{~mm}$. More males compared to females participated in the study. Fitzpatrick skin type was not indicated. The investigators applied nitric-zinc oxide solution with a dedicated applicator brush to obtain a whitish/yellowish skin reaction. This was done every other week, with a maximum of four applications. Clearance was evaluated using clinical and dermoscopic criteria at eight weeks and two months. A 5-point score with the following categorization was used: Complete response - clearance; Good response - sizereduction > 70\%; Partial response - size reduction 50-70\%; Poor response - size-reduction < 50\%; and No response. Complete clinical and dermoscopic clearance was observed in $74 \%$ of lesions, at an average of three applications. No relapses were seen after a six-month follow-up period. Adverse events noted were slight transient, post-treatment erythema and minimal residual hypopigmentation. ${ }^{13}$

\section{Case Reports}

\section{Potassium Dobesilate 5\% Cream}

This study enrolled a 70-year-old woman with two seborrheic keratosis lesions on the face. The size of the lesion and Fitzpatrick skin type were not indicated. The patient applied the medication daily for six months. Clearance was evaluated and was defined as the clinical disappearance of lesions. At the end of treatment, the patient had complete clearance of lesions. Results were maintained after one year. No application-site reactions, skin atrophy, disturbances in pigmentation or skin thinning were observed. ${ }^{14}$

\section{Fluorouracil 5\% Cream}

The lesion studied was an $8 \times 6 \mathrm{~cm}$, elevated, brownish, verrucous plaque on the scalp of a 44-year-old male. The patient was diagnosed to have seborrheic keratosis through clinical and histologic findings. Fitzpatrick skin type was not indicated. Fluorouracil 5\% cream under a polyurethane occlusive dressing was applied daily for 21 days. Clearance was evaluated and was defined as the appearance of normal-looking skin with long hairs on the previously affected site. On the $21^{\text {st }}$ day of treatment, the lesion was completely eroded with most hairs remaining undamaged. Clearance was observed at six months post-treatment. No recurrence was seen after seven years. Adverse events during treatment were erythema, edema and erosion, which resolved after a few weeks. Post-inflammatory pigmentation was the only persistent adverse event. ${ }^{15}$

\section{DISCUSSION}

This study is the first systematic review of topical treatments for seborrheic keratosis. Clinical researches on the topic are limited, with a low level of evidence.

The studies included in this review were able to demonstrate that there is a role for topical medications in the treatment of seborrheic keratosis. In most of the studies, seborrheic keratosis lesions were noted to have good to excellent response to treatment. When compared to placebo, the medications applied were more effective. However, in comparison to cryotherapy, topical treatment was less effective.

Adverse events during and after treatment were mild, tolerable and transient. The only persistent adverse event seen was minimal residual hypopigmentation in one patient.

Patients included in the studies were in the elderly group, with a mean age of 59.4. Treated lesions had a diameter of 5-15 mm, located on the face, extremities, scalp, and trunk. The mean clearance time was 3.5 months.

\section{Limitations of the Review}

The major limitation of this study is the small number of researches done on the topic. Most of the studies have a high risk of bias and are therefore inconclusive. The heterogeneity between the studies did not allow the researchers to conduct a meta-analysis. Studies included had varying study designs and included different study populations. Anatomical areas treated, characteristics of lesions, frequency, and duration of application of treatment 
differed across studies. There was also a lack of consistency in the assessment of efficacy - complete clearance was not clearly defined in some of the studies.

\section{CONCLUSION}

Most patients with seborrheic keratosis treated with the following topical medications had good to excellent response to treatment: hydrogen peroxide $32.5 \%$ and $40 \%$ solution, tacalcitol $2 \mu \mathrm{g} / \mathrm{g}$, calcipotriol $50 \mu \mathrm{g} / \mathrm{g}$ and maxacalcitol $25 \mu \mathrm{g}$ ointments, ammonium lactate $12 \%$ lotion, tazarotene $0.1 \%$ cream, trichloroacetic acid $65 \%$ peel, urea $50 \%$ ointment, nitric-zinc 30-50\% solution, potassium dobesilate $5 \%$ cream and fluorouracil 5\% cream. Among these, the qualitative analysis showed that high concentration hydrogen peroxide $(32.5 \%$ and $40 \%)$ presented the highest level of evidence and was shown to be significantly more effective in lesion clearance compared to placebo. Topical treatments were generally well-tolerated with a few minor adverse events that resolve upon discontinuation of treatment. Hence, topical treatment may be considered as a viable option; however, the quality of current evidence is low due to the lack of randomized controlled trials. Further studies are needed to determine the efficacy and safety of these topical agents and standard invasive therapy remains to be the mainstay of management.

\section{Implications for Clinical Practice}

In this review, the medication with the greatest evidence is the high concentration hydrogen peroxide solution. Different concentrations of hydrogen peroxide are widely available and are relatively cheaper compared to the other medications studied. The A-101 solution is currently being marketed in the US as an applicator pen, which can be easily applied by a physician. However, due to the unavailability of the topical solution in the Philippines and the lack of further studies, at present, electrodessication or cryosurgery remains to be the preferred option.

\section{Implications for Future Research}

More studies, particularly randomized controlled trials, are needed to ascertain the effectiveness of topical treatments for seborrheic keratosis. There should be a uniform study protocol, with a standard measure for reporting clinical results. Both clinician and patient-reported outcomes should be evaluated.

\section{Statement of Authorship}

All authors participated in data collection and analysis and approved the final version submitted.

\section{Author Disclosure}

All authors declared no conflicts of interest.

\section{Funding Source}

This paper was funded by the authors.

\section{REFERENCES}

1. Requena L, Requena C, Cockerell CJ. Benign epidermal tumors and proliferations. In: Bolognia JL, Jorizzo JL, Schaffer JV, eds. Dermatology, 3rd ed. Philadelphia: Elsevier Inc; 2012. pp. 1795-1798.

2. Jackson A, Colver G, Dawber R. Cutaneous cryosurgery: principles and clinical practice, 3th ed. New York: Taylor \& Francis; 2005.pp. 239.

3. Thomas VD, Snavely NR, Lee KK, Swanson NA. Benign Epithelial tumors, hamartomas, and hyperplasias. In: Goldsmith LA, Katz SI, Gilchrest BA, Paller AS, Leffell DJ, Wolff K, eds. Fitzpatrcick's Dermatology in General Medicine, 8th ed. New York: McGraw Hill Inc; 2012. pp. 1319-1323.

4. James WD, Berger TG, Elston DM, Neuhaus IM. Epidermal nevi, neoplasms and cysts. In: James WD, Berger TG, Elston DM, Neuhaus IM, eds. Andrew's Diseases of the Skin, 12th ed. Philadelphia: Elsevier Inc; 2016. pp. 630-632.

5. Review Manager (RevMan) [Computer program]. Version 5.3. Copenhagen: The Nordic Cochrane Centre, The Cochrane Collaboration, 2014.

6. Orence MR, Barcelona-Tan J, Bince BB. Imiquimod 5\% cream as treatment for facial verruca plana: an open label clinical trial. J Phil Dermatol Soc. 2005; 14(2):34-40.

7. Dubois JC, Jarratt M, Beger BB, Bradshaw M, Powala CV, Shanler SD. A-101, a proprietary topical formulation of high-concentration hydrogen peroxide solution. Dermatol Surg. 2017; 1-11.

8. Mitsuhashi Y, Kawaguchi M, Hozumi Y, Kondo S. Topical Vitamin D3 is effective in treating senile warts possibly by inducing apoptosis. J Dermatol. 2005; 32(6):420-3.

9. Klaus MV, Wehr RF, Rogers RS 3rd, Russell TJ, Krochmal L. Evaluation of ammonium lactate in the treatment of seborrheic keratoses. J Am Acad Dermatol. 1990; 22 (2 Pt 1):199-203.

10. Herron MD, Bowen AR, Krueger GG. Seborrheic keratoses: a study comparing the standard cryosurgery with topical calcipotriene, topical tazarotene, and topical imiquimod. Int J Dermatol. 2004; 43(4):300-2.

11. Chun EY, Lee JB, Lee KH. Focal trichloroacetic acid peel method for benign pigmented lesions in dark-skinned patients. Dermatol Surg. 2004; 30(4 Pt 1):512-6.

12. Burkhart CG, Burkhart CN. Use of a keratolytic agent with occlusion for topical treatment of hyperkeratotic seborrheic keratoses. Skinmed. 2008; 7(1):15-8.

13. Lacarrubba F, Nasca MR, Verzì AE, Micali G. A novel topical agent in the treatment of seborrheic keratoses: a proof of concept study by clinical and dermoscopic evaluation. Dermatol Ther. 2017; 30(5).

14. Cuevas P, Angulo J, Salguero I, Gimenez-Gallego G. Clearance of seborrhoeic keratoses with topical dobesilate. BMJ Case Rep. 2012; 2012. pii: bcr0120125628.

15. Tsuji T, Morita A. Giant seborrheic keratosis on the frontal scalp treated with topical fluorouracil. J Dermatol. 1995; 22(1):74-5. 